\title{
From Beveridge to Turner: Laissez-faire to Neo-liberalism
}

Current attacks on pensions can be seen as part of the neo-liberal project to undermine welfare provision. This paper argues that current attacks upon the pension system are not new; Since 1601 the very need for pensions has been questioned by the Right, with arguments usually orientated around; affordability and individual responsibility. An historical comparison shows that many of the commonly held assumptions and arguments against pension provision are often mistaken, and in some cases highly misleading. Discourses or ideologies, touted in the 1940s are being re-used in the current period. This paper identifies which arguments were misleading or false in the past, thus allowing us to see through them in their current form.

In this paper previous tendencies driving the conceptual apparatus of laissez-faire policies are re-visited, albeit with some new twists, in the guise of the neo-liberal project.

Pensions, Welfare State, neo-liberalism, laissez-faire, historical comparison, the third way, discourse. 


\section{Introduction}

The real and current pension crisis is relatively simple to express; not only are there currently too many people in poverty in old age; that number is set to increase if current government spending policies continue (Davies, 2003, 9). The cause of the 'pension crisis' is debatable; is it simply the case that individuals are not saving enough? Or have people been let down by pension schemes? Do many workers earn enough to contribute meaningfully to a pension fund? In the UK the Pension Commission was established by the government in 2002 to investigate the current pension crisis.

There have been two Pension Commission reports, both of which were chaired by Lord Turner; the first report, published in February 2005 and entitled Principles for Reform: The national pensions debate (PC 1 2005) outlined a number of issues connected to pension provision, but did not offer much in the way of proposals for change. A second, more detailed report, therefore was commissioned. The second report would make recommendations for future government policy. The focus of this article is the second, and most recent Pension Commission report, Security in Retirement: Towards a new pension system (PC 2 2006), which will be referred throughout this article as the Turner Report, published in May 2006. This second report, whilst being different in scope to the Beveridge report is similar in other aspects. If we just look at the contribution of both reports to the field of pension provision, we can recognise that both the Turner and the Beveridge reports were concerned with examining and recommending changes to a pension system that it was felt needed reform. Indeed, John Hill, who was a member of the Pension Commission has written about how the Pension Commission compared their findings to Beveridge's, and agreed with some of the key principals of the Beveridge Report (Hills, 2006, 13)

This article will argue that the type of reform suggested by the respective reports reflects the political economy of the era and climate in which they were produced. This article will suggest that the Beveridge report was produced in a climate that was open to a number of potential pension systems, and that whilst some of Beveridge's proposals were blocked or restricted by Treasury employees, and indeed the financial realities of post-war Britain, the report that was published reflected one aspect of a wider pensions discourse - a discourse that had not yet become standardised or indeed hegemonic. It is argued however, that the Turner report, which had similar objectives to Beveridge's, did not enjoy the same discursive freedom. The Turner Report was tied to the conclusions of the first Pension Commission's report, and both reports seemed clearly aligned to New Labours 'third way'. The Turner Report, for example, cherry-picks which aspects of Britain's legislative pension history is included in the report, and underplays the impact of pension mis-selling and employer contribution holidays, whilst at the same time puts promotes and places an emphasis on greater personal responsibility. This is important, as it suggest that a significant 
cause of the current pension 'crisis' is individual reluctance to prepare for retirement, which if true, can only be partly to blame. An emphasis on the responsibility of the individual also suggests that the State is not responsible, and should not be responsible for doing this. John Hills article argues that the Turner Report was torn between two extremes;

At one end, some have argued that the State's role should or can only be that of poverty relief. At the other, people argue that it is the state which should organise and provide earnings-replacement for all or nearly all (Hills, 2006, 14)

It is difficult to find evidence of this turmoil in the actual report, and significant recommendations of the report, that the link with earnings for the state pension should be restored, and that Personal Accounts should be created, along with the individual choice to opt-out represent an uncomfortable compromise. Whether New Labour will ever restore the link with earnings is still not yet certain, and if this is to happen, it will not be before 2012 .

Beveridge was very clear that social insurance should be a relationship characterised by joint responsibility between citizen and state, and that so long as individuals fulfilled their responsibility by working, then the state should fulfil its responsibility by providing people with insurance - which is in this instance, a secure pension. This is a sentiment that Hill has argued that the Pension Commission agreed with (Hills 2006, 13). It seems, however, that sixty years on the commitment to this relationship of joint responsibility is being renegotiated, and the meaning of responsibility manipulated.

After comparing the Beveridge Report, and the Turner Report, this article draws our attention to two basic discourses; affordability and individual responsibility. According to Fairclough (2003) discourses, are not just ways of representing the world, they can influence the world. What is said or written, can causally influence what we subsequently do, making discourse a potential cause of social action. Discourse influences action by selecting and emphasising certain linguistic, and hence practical possibilities, whilst de-selecting, deemphasising or excluding others, making these other linguistic and hence practical possibilities far more likely to occur. Fairclough (2004) is careful to point out, that just because discourse can 'construe' the world, it does not mean that discourse can re-construct the world. Understanding discourse in this way allows us to hang onto the notion that what we say, or write, about practices related to pension provision can have causal efficacy, without lapsing into the idealist trap whereby what we say or write creates or constructs these practices. Put simply, by selecting and emphasising certain linguistic, and hence action, possibilities and de-selecting, de-emphasising or excluding others, some discourses relating to pension provision may become accepted true - even if they are false (Fleetwood, 2005, 200).

This paper compares and contrasts discourses of affordability, and individual responsibility between the 1940s and today. It demonstrates how different contributors to the 
pension debate, select and emphasise certain discourses whilst de-selecting, de-emphasising or excluding others, making these other discourses and, thereby, practical, possibilities far more likely to occur. In so doing, it reveals that reports such as Turner's and Beveridge's are more than large tomes that gather dust on library shelves: they contribute to the political climate in which pension provision is carried out, making them an important factor in the economics and politics of the contemporary pension crisis.

It is necessary to briefly describing what is unique about the current neoliberal period, as whilst there are numerous similarities between Thatcherism and New Labour there are also some distinct differences. These differences are the result of New Labours experimentation with the 'third way'. In New Labour, New Language? Fairclough describes how New Labour have built a new political discourse by incorporating 'elements of the political discourse of Thatcherism' into their own discourse (Fairclough, 2000, 21).

Thatcher's Conservative government of the 1980s explicitly targeted those who claimed various benefits. New Labour however, do not employ such openly aggressive discourse, favouring an emphasis on encouraging people to help themselves; 'helping people back to work, helping people off benefits, helping pensioners out of poverty'. The current discourse focuses almost entirely on individual rights, and responsibilities - responsibilities which on closer inspection are also emphasised in the Turner report. Fairclough notes that this

'moral discourse is combined with contractual discourse which interprets the distribution of rights and responsibilities metaphorically as a contract or deal between the individual and society (the community) or the individual and the government (Fairclough, 2000, 39).

Appeals for personal responsibility are combined with economic arguments over pension provision affordability, regardless of whether the sums actually add up or not. These moralistic appeals that we take responsibility for ourselves, and not rely on the state are softened by traditional left-wing Labour commitments to poverty prevention, albeit with a means tested pension credit, which reinforces the contractual discourse of neoliberalism. Personal Accounts, Pension Credit and an emphasis on personal responsibility reflect,

'the moral and contractual discourse of New Labour as an individualist discourse, which stands in contrast with the traditional collectivism of the centre-left and the left. The 'deals' that are contracted are primarily envisaged as deals which individuals enter into, the 'responsibilities' and 'duties' are primarily those of individuals. New Labour has abandoned even a residual orientation to collectivism and to social class'. (Fairclough, 2000, 40)

The unquestioning acceptance of these individual contracts and responsibilities is what current proposed pension reform is based on. It is based on the assumption that everyone is able to provide for their own retirement, without an investigation into individual 
circumstances. It encourages people to think individualistically, as opposed to the collectively. Social security was a form of insurance that one could, if necessary, claim for a limited period, or in certain circumstances, indefinitely. It was not vilified as a crutch for those who do not want to work, as opposed to cannot. This new neoliberal notion of responsible social security, however, seems only to go one way. For instance, in the Turner Report, the lack of responsibility the Thatcher government displayed when it encouraged millions to opt-out of SERPS and then were mis-sold private pension schemes is underplayed. Despite this, the discourse of responsibility seems to be an enduring and captivating one. This article aims to demonstrate that neoliberal discourse, characterised initially by Thatcherism, and most recently by New Labour's 'third way', has become naturalised and hegemonic. It is no longer a competing discourse, but rather the discourse. To deviate from it is seen as illogical, and uneconomical. Discussing the dominance of neoliberalism discourse Henk Overbeek comments that,

'Untrammelled international competition, the celebration of the market, or wealth and self, anti-communism and anti-unionism; all these are no longer propagated as 'revolutionary' in a sense of challenging a prevailing consensus of a different content, but they are now part of normal every day discourse, self-evident, near impossible to contradict or even doubt. History conceived as struggle of ideologies has come to an end as Fukuyama (1989) would have it ... Its (neoliberalism) victory means that its radical tenets have themselves become the new 'normalcy'. (Overbeek, 1993, 1-2)

It is this normalcy that this article is concerned with identifying and presenting.

The methodology used to interpret the documents used in this article have been informed by a broadly realist perspective. The figures used in any discussion of the pension crisis are a form of discourse, as are the government documents that have been used, and discourses are not always true: they can differ from, or fail to express, practices. This article will demonstrate that discourses that are false (ideologies) are being re-used. They were false in the past, and looking at them again allows us to question the truth of their current versions.

This article is historically comparative, and as such it draws on documentary evidence from the National Archive (NA) and a range of official governments publications. Whilst government documents are generated for a specific purpose, the comprehensiveness of the Beveridge Report means that the NA contains not only official government views but those of contributors who had a vested interest. The proposals of the Beveridge Report were somewhat controversial and had various implications for different departments. As a result material exists that gives a genuine insight to the opinions of those involved. Furthermore, even official documents are supplemented by the comments and marginalia of various officials who considered them - as such a clear view of what was intended can be discerned. 
Current such government documents are not available; therefore I am forced to rely on publications such as the Turner Report and government White Papers. It is more difficult to gage political opinion on such matters due to the efficient operations of Party spin machines. It was only from comparing different historical eras to the present that one is able to accurately identify the enduring discourses. Though it may be perceived that this article is selective about the discourses it presents, and this could be a criticism of the theories being put forward, the research undertaken was done so in the spirit of good historical research, to uncover, and to present; not to mislead. It was with this in mind, that the article was written.

\section{Affordability}

Between 1946 and today, there has been something of a rough and ready all-party consensus that pension provision is affordable. It is important, there fore, to examine the arguments that have led to a significant change in this belief that survived despite the introduction of the BSP, and often cite affordability as the main obstacle. Neoclassical economists (and policy makers inspired by these economists) believe, and argue that the best way to secure decent pensions provision is via the free market: everyone should have an individual private pension plans - restricting the need and scope for state provision. Blackburn (Blackburn, 2002, 431) suggests that it was only the 'experience of war time collectivism' that provided the inspiration for a universal pension which amongst other factors, is probably true Individuals and their families were responsible for saving privately for old age - a sentiment that remains today. Encapsulated in this view of affordability is the idea that offering any form of welfare will discourage thrift and saving. Affordability, and discouraging saving are, however, separate arguments, but the latter is often used to support the former. This section, then, will deal with two themes, present in a discussion of both past and current - first, the question of whether pensions are actually unaffordable; second, whether current discourse presents pensions as being unaffordable. The former refers to how economic concerns are raised to object to plans for universal pension coverage, whilst the latter refers to how the discourse of what is, and what is not, affordable restricts what is even considered in relation to pension provision (and how due to a lack of any alternative discourses the scope of what can be considered is becoming ever decreasing.

\subsection{The discourse of affordability - past}

The outbreak of World War Two had, naturally suspended a planned debate on pension reform. Rising poverty, and protests from both the TUC and the Scottish Minister for Health had meant that in 1940 pensions reform could not be ignored any longer, causing the Chancellor of the Exchequer to present a memorandum that claimed that 'since the Poor Law was established in this country the aged and infirm have ultimately been a charge on local 
resources', ${ }^{1}$ and therefore are not the responsibility of government. Government could not afford to have this 'charge' transferred to them, particularly during wartime. The dominant inference of the memorandum was a recognition that to provide for the elderly, even at the below subsistence level that the Poor Law did would be too costly. Government did not want to pay for a central Poor Law and were certainly not going to support a system of welfare provision which would be even more costly.

Nevertheless the issue of pension and welfare provision more generally remained an impassioned public issue and the Beveridge Report was commission two years later. The quarrel of the Chancellor of the Exchequer with pension provision resurfaced not only in the drafting stages of the report, but during the discussions of numerous committees that followed it. It was felt that a universal pension would equate to a free meal ticket for every idle man in Britain, and would discourage thrift, making a pension system unaffordable, as it would be supporting everyone.

The financial practicalities of the Beveridge Report were decided by the committee (set up to discuss the report) before any evidence of the affordability was actually presented. In his 1940 memorandum the Chancellor of the Exchequer had referred to correspondence he had received from the British Employers' Confederation who recommend,

husbanding our financial resources for the successful prosecution of the war, and that if government lent its support to any flat rate increase, however paid for, irrespective of need, it cannot fail to create the impression that this country can afford to dissipate its income on non-essential purposes without thereby endangering the country's security - an impression which must inevitably encourage wage claims by workers actually at work, and undo a large part of the educational work regarding the dangers of inflation which the chancellors speeches were designed to achieve. ${ }^{2}$

Wartime collectivism was exploited by those who simply did not want to see an introduction of a universal pension under any circumstances. In this respect, the war provided a political and economical distraction - and those who continued to campaign over pensions were in some way hindering the war effort by making government focus on 'non-essential purposes'.

One of the main concerns over the affordability of Beveridge's proposals was that essentially it was a plan to redistribute some of the nation's wealth. Beveridge felt that 'taxation means the richer man, because of his capacity to pay, pays more for the general purposes of the community. These general purposes may, and in practice they must, include bearing a part of the cost of social security' (Beveridge, 1942, 108). According to Beveridge's plan there would be permanent contribution to the pension's scheme from direct taxation. This would mean that for the first time, money, generated through taxation, would be directed into the purses of the less wealthy; it would not be received from assistance 
boards or through the Poor Law. Naturally, the capitalist class would resist such a scheme at all costs, and advance political, economic, and patriotic arguments to support why they are unaffordable - but the political tide was starting to turn against them. Given the climate produced by World War Two, which forced conscripted men to fight, for the moment, at least, arguments against pension provision based on unaffordability discourse were shelved.

Despite numerous protestations to the contrary, according to all the projections from the Government Actuary Department (Beveridge, 1942, 173-21) it was considered that the plan for universal pension coverage was affordable. ${ }^{3}$ Those within the Treasury and the International Labour office (including Lord Keynes), however still felt that Beveridge's plan to provide a pension for all was unnecessary as: 'to set out to abolish 'want' where it does not exist is like Quixote charging the sheep and gaining an easy victory. ${ }^{4}$ The debate shifted from an ideological debate focussing on the question of providing a universal pensions (which the ruling class could see was already lost), to a debate focussing on the question of affordability, as it was felt unnecessary to provide for all, as the financial position of old age pensioners shows more variation than would be found in nearly any other part of the personal insured field. This reappearance of reluctance to introduce a comprehensive scheme, despite proof of its affordability is still as prevalent today. The main difference being that the current situation has regressed to pre-1942, and the belief that a universal pension system is not affordable.

The British Employers Confederation (BEC) never demonstrated any will to see the state pension introduced, indeed government documents suggest that the BEC attempted to delay the progress of the Beveridge Report by refusing to contribute when requested. Only when it became clear the report would be published regardless of their cooperation and contribution did the Confederation publish a memorandum. Echoing earlier protestations made to the Chancellor of the Exchequer in 1940 the BEC claimed that fighting the war effort was entirely consuming for businesses; such matters should wait until the war was won.

This is despite the fact that businesses, and those involved in the BEC, on the whole, were financially better off post World War Two than before it. It is questionable, therefore, to what extent employers could not afford the increased contributions a universal pension would entail - using the war as an easy scapegoat. The Confederation maintained that the economy could not afford increased pension provision stressing that such a plan would prompt a return to the depression and unemployment of the 1930s claiming that,

We are convinced [the BEC] that this colossal expenditure on social security (at that time $£ 400$ million per year) is far greater than this country can afford; the financial burdens it places on industry are, in no small measure accountable for our depression, and that this country, in concentrating on insuring its people against all the risks of life, has in large measure deprived them of employment, which is the greatest security of all. ${ }^{5}$ 
The Confederation did not provide any evidence in their memorandum to support the claim that social security spending caused the Depression of the 1930s, and it would appear that the Treasury did not treat it very seriously as eventually it was admitted that despite many objections from opponents, or political will against reform, some of Beveridge's proposals would have to be adopted. As Wilfred Eady conceded 'that the political and economic background immediately after the war may need something on these lines to reduce the field of internal controversy'. ${ }^{6}$ Offering post-war concessions would hopefully keep political agitators silent, and keep revolutionaries and other militant factions, especially the Communists within the Trade Union movement on the periphery.

\subsection{The discourse of affordability - present}

We are told by economists that pension provision is an escalating cost of developed countries due to enjoying an ageing population. This is, undoubtedly true, as:

The direct costs to public expenditure attributed to people aged 65 and over were estimated at $£ 8.4$ million for health care and $£ 2.8$ million for social service (England and Wales) in 1989-90; $£ 23.8$ million for state pensions (Great Britain) in 1990-91. By far the greatest cost is that of pensions. (Thane, 2002, 481).

It is not the intention of this paper to paint this as some political myth - pension provision is expensive. What is under question at the moment is whether or not it is affordable. Recent reports about the future of the welfare state and pension provision request major changes due to the unaffordability of the scheme, despite the fact that,

The distribution of costs and the total pensions cost is likely to remain stable until c.2020 since the total population of pensionable age is expected to be stable, unless there is a significant rise in state pension expenditure, or a significant shift in priorities for welfare spending, of which there was little sign in the late 1990s in the political statements of either main political parties. (Thane, 2002, 481)

It appears therefore, that agitation over the affordability of pensions is connected to political will, rather than strict economic logic. Current political decisions are being made about the extent to which the cost of pensions should fall upon the individual or upon public expenditure - the affordability of universal pensions, and the strain on the taxpayer, is just one of the factors affecting this debate. The real factor is as relevant now as it was in $1946-$ the discourse of affordability. By restricting the terms of the debate, the discourse of affordability restricts what is considered, what can be said and, therefore, influences what can be done. To a certain extent the Beveridge reflected this, and the Turner Report currently demonstrates this. 
The New Labour lexicon tends to avoid directly discussing the details in reference to affordability. Rather, there is much made of lifting the poorest out of poverty, and hence, highlighting the benefits of maintaining the means test:

'Our changes to the state pension system since 1997 have been essential to tackle the immediate problems that we found, and, as we have set out, they have been very successful. Incentives to save in the current system remain strong. Recent research has shown that incentives for many on low incomes have improved as a direct result of the introduction of Pension Credit'. (PC 2, 13)

Rather than having a debate about affordability, the discourse focuses on targeting resources, and helping those that are most in need. It becomes difficult to criticise these arguments without ultimately criticising the whole of New Labour's welfare strategy, as it relies on this principle. Be that fuel allowance, or pension credit - the aim is to help the poorest. So by focusing the debate on the poorest, the discourse prevents it from moving onto a more thorough discussion of how much GDP we should spend on pensions - indeed, this is not debated, despite being a logical discussion to have.

A further example can be found in John Hutton's introduction to the report, where he comments:

'Protecting the poorest - we are committed to uprating the Guarantee Credit for pensions in line with earning growth. This means the value of the $£ 1145$ guaranteed minimum income for single pensioners today will keep in pace with the growth in national wealth'. (PC 2, 22)

This is not a commitment to eradicating pensioner poverty, just managing it. It is the endurance of the means test that highlights affordability as a hegemonic pension discourse, and whilst the focus of the debate has shifted slightly, the message is still the same as when it was falsely touted in the $1940 \mathrm{~s}$ - pensions are not affordable.

In 1942 Beveridge set out an affordable plan for universal pension provision; in 1946 Atlee cherry-picked from the plan. Gordon Brown in his previous capacity as the Chancellor of the Exchequer, and now as Prime Minister is guilty of doing the same. The Turner Report shares some similarities with the Beveridge Report, though it is probably fair to say that the remit of the Turner Report was more greatly controlled - for example despite Turner's enthusiasm to see the link between the state pension and earnings renewed, it has been postponed until 2012, reportedly at the behest of Brown. Turner has also recommended raising the retirement age due to higher life expectancy figures. This is however, in the shadow of a government (and sections of business) who are reluctant to raise the retirement age.

As noted already, due to both their importance for a minimum of financial security in old age, and their general popularity with the voting public, pension are not going away (yet), 
therefore, the perceived unnecessary cost of providing a pension to those who do not require the money - wasting money on already wealthy pensioners - is being renegotiated. The Minimum Income Guarantee (MIG) was introduced so that supplementary benefits could easily be targeted at the poorest of pensioners and designed to bring them above the poverty threshold. This would help the government reach its targets, without having to consider a whole scale rise in pension payments - which pleases the Treasury, many (but not all) tax payers, and keeps political opponents silent, and more importantly, does not evoke negative discourse associated with 'means-testing'.

The preoccupation with not becoming a Santa Clause state - something for nothing (a concern as relevant to Beveridge as Turner) - has, however, led to a nothing for something state pension system which is currently not rewarding large proportions of citizens who have worked - in particular, women. In short, it would appear that since the 1930s little has changed for the poorest of pensioners, as they are still dependent on supplementary benefits and to our shame, the poorest of these elderly are still women. Due to the nature of the traditional caring role of women in society they receive irregular records of employment, and contribute less to national insurance, currently resulting in below subsistence pensions (Thane, 2006a). The prevention of this scenario was the main reason why Beveridge insisted that all citizens should receive as subsistence level pension, and that widows should receive particular attention during any pension reform.

The government now is proposing a 'New Deal' for female pensioners, who are set to suffer the longest whilst delays continue in restoring the earnings link to the BSP, as even a reduction in the number of years required contributions will take along time to benefit all women. It is also unknown what impact the government's aim to get 50 per cent of the population into university will have upon pension provision, national insurance contributions, and retirement age - as the age for entering the labour market becomes roughly $21 / 22$ years old, rather than 16 .

Regardless of some noble proposals for pensions, Lord Turner has written within the Labour Government's discourse of affordability; matching his proposals very closely to the 'fiscal and political difficulties of financing pensions' (Thane, 2006b) that the government claims it faces. In some ways it would have been impossible for Lord Turner to have produced anything else. In the 1940s there were many competing discourses, and not one overarching hegemonic discourse; as neoliberalism is now. In many ways, anything was possible. This is simply not true of the current situation, as quite often we are led to believe the discourse of TINA; there is no alternative. Even the TUC General Secretary Brendan Barber is supporting government reforms to the pension system, commenting on the subject of the proposed 'Personal Accounts': 'while it is right to examine the position of the low paid, critics of the new scheme fail to see that most people would rather build up their own pension 
pot, rather than rely on the future vagaries of state pension benefits' (Labour Research Department, 2007). This discourse which, as noted above not only supports the view fostered during the 1980s that state saving is somehow negative - a bad way to save - and that a greater return can be found in the private sector, but also reverses the polarities on state and private pensions and refers to state pensions as having future vagaries, but not private pensions, which are rooted in the real vagaries of the stock market.

\subsection{Summary}

Current opposition to improvements in the pension system and opposition to the very introduction of a universal pension system in the 1940s on the grounds of affordability are couched in very similar discourse. Indeed, they are so similar it is difficult not to see systematic political social and economical forces at work.

The Beveridge Report proposed major changes not only to pension provision, but social security as a whole. The welcome given to the Beveridge Report was 'that of a still largely impoverished working class, with memories of still greater, recent, misery and with low expectations of how their living standards might rise' (Thane, 2002, 368). There was a sense of public elation surrounding Beveridge's proposals, which gave people hope of a better life after the war, and strong consistent opposition from the Conservative party who regarded 'Beveridge's proposals as genuinely undesirable' (Thane, 2002, 368). The threat of a revolution after World War Two was a very real fear for the government - the 'spectre of communism' was crucial in shaping political-economy of the period after World War Two. The threat from Bolshevism was real and the ruling class were worried that the aftermath of World War Two would see the rise of 'communism' (more appropriately, Stalinism) in Europe and the UK. Added to this the working class were organised, militant, capable of military fighting, and had ideological support from the fact that capitalism was tainted with fascism and 'communism' appeared to have the higher moral ground. This situation led to concessions being given (in the form of welfare) that might otherwise not have.

\section{Responsibility}

The question of who bears the responsibility to provide welfare provision is a long standing debate. The Beveridge Report appealed to a notion of joint responsibility; that every individual, completing work within their power, should be guaranteed at least a subsistence retirement income - as it was the State's responsibility to rid society of want - one of the 'Five Giants'.

In more recent years this perceived responsibility to provide a pension on retirement has been questioned. This paper has already examined the changing nature of affordability of the state pension and given an alternative analysis of the nature and impact of an ageing 
population. This Section will seek to address the changing representations, discourse, and nature, of responsibility, from the early twentieth century, to the early twenty-first century. It will analyse the political, ideological, and economical factors affecting change.

\subsection{The Discourse of Responsibility - past}

Before the introduction of the Welfare State it had very much been the case that individuals and their families were responsible for saving privately for old age; the state it was argued could not and should not adopt responsibility to provide this.

This view of pension provision (and welfare as a whole) was popular amongst Conservative political circles at the time of the writing of the Beveridge Report - who formed the bulk of the war-time coalition government. It was strongly believed by many on the right (and still is) that the primary objective of welfare was poverty relief - nothing more. Any universal pension would be directing money were it was not required, or where there was not poverty. Beveridge recognised the obstacles facing comprehensive welfare provision and commented that, it would be down to British citizens to fight for universal social security:

'Freedom from want cannot be forced on a democracy or given to a democracy. It must be won by them. Winning it needs courage and faith and a sense of national unity; courage to face the facts and difficulties and overcome them; faith in our future and in the ideals of fair-play and freedom for which century after century our forefathers were prepared to die'. (Beveridge, 1942, 172)

Beveridge, an experienced politician and Liberal peer predicted the difficulties his plan would face, and was familiar with the types of arguments that would be used to counter it. None of Beveridge's proposals were new per se, but it was the first time they had ever been included in such a comprehensive document. Anti-welfare discourse and sentiments persisted, and in the 1950s the Conservative party released a document stating,

'The Conservative Party does not regard the true function of the social services to be either the provision of an average standard or the redistribution of wealth. It approves the historic function of the social services as the relief of the unfortunate from misfortune, of the sick from ill-health, of the needy from distress (Thane 2002, 371)'.

The Beveridge Report had challenged these principles of welfare; however, opposition never disappeared, resurfacing in the 1950s, 60s, 70s, and again in the 1980s, when the neoliberal discourse relating to pension reform, started to become hegemonic. The above quotation merely highlights that this type of rhetoric has never left the political lexicon of the right (it was just not always stressed).

\subsection{The Discourse of Responsibility - present}


Throughout Margaret Thatcher's leadership the Conservative government never displayed a coherent approach to welfare provision. A formal abandonment of the full employment goal appears to have been a precaution against political failure considering the large losses in manufacturing jobs during the 1981-82 recession.

Further attempts to distance government from the responsibility of providing pensions is evident in the implicit privatisation of SERPS (Pierson, 1994) and the introduction of personal pension schemes which were a major welfare innovation of the Conservative Party - these pensions have since been discredited by the mis-selling scandal, which saw people persuaded to leave their occupational scheme for the (as it turned out, false) promise of a better returns. It is possible now to see that during the 1980's the future of welfare in Britain and the state's relationship to it underwent a re-examination. As did the discourse used to describe welfare; the homeless became rough sleepers. Claiming benefits, or using the service of the welfare state became refashioned to be something one should be shamed of, rather than celebrating, as a generation previously had done. It was also during this period that services provided by the state came to be regarded as second class services.

The state abandoned any ideological responsibility to provide welfare, and encouraged private citizens to view those that accepted welfare in a negative way. In September 1983 for an interview with Woman's Own Margaret Thatcher declared,

'I think we have gone through a period when too many children and people have been given to understand "I have a problem, it is the Government's job to cope with it"... "I am homeless, the Government must house me!" And so are casting their problems on society, and who is society? There is no such thing! ... I think, one of the tragedies ... that many of the benefits which were meant to help people who were unfortunate, somehow there are some people who have been manipulating the system'. (Sunday Times, 1987, 8-10).

The earliest welfare provision, the Relief for the Poor 1601, was born out of a Christian belief that we should take care of those that are less fortunate, that the wealthy have an obligation to provide for the poor - over the last twenty years in Britain the dominant discourse espouses that those less fortunate are to blame for their position, and do not deserve help. Our moral responsibility to society and commitment to a better world has been eroded, aided and abetted by a powerful leader who promoted a discourse based on the sovereignty of the free market, and the promotion of individual obligation and entitlement, above all else, and above all others. It is now accepted, in many quarters, that it was not prudent in contributing to a state welfare scheme, not only because it was presented as only benefiting the lazy, but also because the money would be better spent in the private sector. This has since proved to be a false discourse, however, the above comment from Brendan Barber demonstrates how this myth is still being peddled, not just by politicians, but by trade unionists. 
The interview Mrs. Thatcher gave to Sunday Times however marked the beginning of a sustained attempt by her government to weaken working class communities. Thatcher created a stigma around claiming benefits such as unemployment benefit - re-branded as Job Seekers Allowance (notice the discourse of personal choice) - that still exists today. People are not claiming what they are rightfully entitled to from an insurance scheme, as Beveridge envisaged it; they are being a temporary drain on national resources. This discourse targeted at benefit claimants has not gone away, and only grown stronger. Powell examines the existence of 'DIY' welfare, where people are urged to become more responsible and make provisions for the risks that they and their families face. However, the private pensions misselling scandal and the Maxwell pensions fund scandal, let alone the Conservatives changing the rules of SERPS and New Labour taxing pension credits make DIY welfare a risky business' (Pierson, 1994, 289) that any rational person would chose to avoid.

In contrast to the Beveridge Report, the Turner Report suggests action on the pension crisis on a technical, rather than moral basis. Lord Turner claims action is needed as the future for pensioners without any reform is 'undesirable' (PC 1, 2004). Lord Turner does not criticise this potential outcome, in the way that Beveridge criticised the existence of want in the 1940s; though the Turner report does note that this would be an undesirable option (PC 1, 2005). This is not a commitment to pension from a sense of responsibility - it is a technical fix, and the discourse reflects this. Emotive discussions about pension provision could lead to all manner of outrageous calls, such as higher taxes and are, therefore avoided. The government is simply realising, and reacting to the fact that something will have to be done to prevent poverty in old age - much like the original Poor Law. Since the 1980s the UK has dropped to the bottom of the international league of developed countries for state pension provision (Churchill and Mitchell, 2005, 6). The abolition of the link to earnings meant that in 1997 the UK BSP had become one of the lowest in the EU, worth less than 15 per cent of average earnings; it is set to decline further. The Turner report, therefore suggests proposals based on the requirement to do something, rather than right thing; in this way it is not comparable to the Beveridge report. This can be seen in the following extract from the Turner Report:

\footnotetext{
'we need to be clear that individuals must be responsible for their own plans for retirement. The reforms will ensure the provision of high-quality saving vehicles, and a solid state foundation to private savings. But the choice of how much to save, the level of risk to take with investments, and how long to work must be available to the individual. That provides the right balance of choice and support for individual responsibility. (PC 2, 2006, 22).
}

This particular notion of responsibility is a uniquely New Labour one. There are no mention of the facts and figures, merely a lot of rhetoric and discourse aimed at conveying a 
sentiment surrounding saving that we should all follow. The New Labour discourse transforms pension savings into a lifestyle choice; suggesting that if people do not save enough it is automatically their fault, through negligence. Taking individual responsibility is not the key issue here, as ultimately most individuals already do this. It is the message that accompanies such statements which is significant. The insistence that individuals 'must' be responsible, and that with this responsibility individuals have a 'choice' of how much to save. For the majority, there is not much of a choice; people save what they can. Those with few pension savings are generally those from low income groups who have little extra income to save, whereas the suggestion in this quotation is that there are significant numbers of people with expendable income simply choosing not to save.

There is little mention of the reciprocal responsibility of the government to provide individuals with simple advice, with good regulatory legislation that stops the private sector miss-selling pensions. Rather the world responsibility takes on a new meaning - an extra dimension. By using responsibility in this way, the report seems to suggest that currently people are not taking responsibility and are relying on the state, and/or others. There are no mentions in the report the low levels of trust that impact of the Maxwell scandal and the misselling of private pensions has had, or the impact of employer contribution holidays and the closing of occupational pension schemes. Responsibility is a two way relationship, and not having a significant retirement income does not necessarily correlate with being irresponsible, in the simplistic way that the Turner report suggests. Often, despite a complete and consistent working life, low-wage earners retire reliant solely on modest personal savings, and the state pension. This does not mean they are not responsible individuals, or indeed deserve punishing or scapegoating.

\subsection{Summary}

The changing discourse over whether it is the responsibility of the state, or the individual to provide a retirement income has perhaps being the discourse that has altered most dramatically. Considering the failure of private, stock-market dependent schemes to provide consistent pensions they are still promoted as the future of pension provision. Why? Simply, because there are no alternative discourses out there. The neo-liberal discourse of the market and the success of Thatcherite and New Labour discourse in replacing the collective discourse of Beveridge, has meant that people believe this is the best way, as it is presented as the only way. The state pension has been rundown so much, both in an economic practical sense, and a discursive one, that it hardly seems worth saving.

The Turner Report provides a clear example of New Labours 'third way' political discourse. It includes discourse traditionally associated with Labour values; 'tackling pensioner poverty', 'implementing fair reform', but it also includes discourse that is 
reminiscent of Thatcherism; 'policies must promote greater personal responsibility, 'modernisation of the welfare state'. The mixing of these discourses and messages is what has been so distinctive about New Labour, and in particular Tony Blair; but Blair is no longer Prime Minister and the same discourse continues to pervade. This is the political discourse of British neoliberalism.

Beveridge's 1942 report contributed towards a political consensus and a post-war discourse in relation to welfare. At the time of writing the report, however, this consensus was not present, and there was still no certainty when the Second World War would end. There were competing discourses concerning welfare provision, and pension provision more specifically, but immediately after the end of the war these were either sidelined or suppressed. It did not take long however, for the same old counter-universal pension provision discourses to reappear, as they have done a certain historical points. The notable difference with the Turner report is that it does not explore an alternative discourse, and indeed do not acknowledge that such a discourse exists.

\section{Conclusion}

This article has highlighted that despite serious opposition to the state pension there was never any serious challenge to the system. This meant that critics of the pension system were left with little option other than to (begrudgingly) accept the universal system, and strive to keep payments as low as possible, and funded as little as possible from general taxation as possible.

Since the 1970s, however, there have been moves to renegotiate the 'terms' of the post-war settlement. The discourse of an overburdened state firmly took hold, leading to the current situation where the post-war settlement is not just up for renegotiation, but has been metaphorically 'ripped up'. As mentioned above, in his 1942 report Beveridge noted that: 'Freedom from want cannot be forced on a democracy or given to a democracy, it must be won by them' (Beveridge, 1942, 172). The Beveridge Report was a landmark in social security reform and provided the basis for the current welfare state. It is obvious now, however, that despite significant improvements in social security provision in the UK over the past fifty years, significant social problems, however still remain. This article has suggested that perceived and commonly held assumptions about problems associated with pension provision still remain due to lack of political will and the enduring class structures of a capitalist society - rather than pension provision being an unsolvable puzzle. The last century has witnessed more improvements in welfare than any other century in British history, so there is much to celebrate - but also much to lament.

The UK's poorest elderly are still forced to rely on hand outs from the state, determined by demeaning and extensive means-testing. The severe inequalities that exist 
between rich and poor pensioners have continued. For those in the worst scenarios, little has changed since the publication of the Beveridge Report in 1942. Beveridge recognised the wider political implications of his plan, as he,

believed his proposals could only be fully effective in eliminating Want if supported by a range of measures, including minimum-wage legislation, industrial training, strict price control, statutory limitation of free collective bargaining, public ownership of land and essential services, and, if necessary, the phasing out of private ownership of most of the means of production. Here again, even if theoretically correct he was politically unrealistic. Labour's unwillingness or inability to implement most of these corollaries of his Plan help to explain its extremely limited effects. (Thane, 2002, 371).

The Labour victory of 1945 is partially credited to the Conservative Parties reluctancy to introduce many of the social security measures that Beveridge discussed, however, the Labour Party were not willing to fully implement them either, and passed up one of the few chances in British history to introduce socialist policy. What we have been left with in Britain is a lot of welfare 'churnings', such as the income tax payer who is also claiming winter fuel allowance. This system of churning creates needless administration and bureaucracy.

To say this does not dispose of matters. Suppose someone has not made adequate provision for old age or periods of ill health. In a civilised, afflsuent society he or she should not be left to perish in the gutter. The genuine liberal (neo or otherwise) should ask: what is the minimum standard we wish to provide even for those who have been improvident or unlucky in their personal affairs? (Brittan, 2004)

As noted in this article this view of welfare was abandoned in the 1980s, so that even the minimum should not be provided. The only consistent factor in the long debate over pension provision is that the Conservative party has always attempted to defend middle to upper class interests by opposing changes, reform, or increases in pension provision. It is the Labour Party now however, that is moving towards the Right, and proposing policy that does not defend working class interests - the reason why the Labour Party was originally founded.

It has also been argued in this article that the state should take responsibility for the administration of a public, universal, and non means-tested pension system; experiments with private secondary pensions, as opposed to state secondary pensions, has on the whole, been disastrous. Turner's proposals for a compulsory saving scheme is a noble effort to encourage saving. What is still unclear however, is exactly how Personal Accounts will be administered and maintained. The state pension should function as Beveridge intended; a pension equal to the average wage or at the minimum subsistence level. Those who do not have any other form of superannuation or occupational pension should be encouraged to bolster their 
retirement income with a secondary state pension that would function like SERPS. This would benefit female workers in particular, along with atypical workers, or those trapped at the bottom of the labour market, stuck in short-term employment.

Finally, this article has maintained that a universal, non means-tested pension system is affordable - it is the current political economy of Neoliberalism that maintains it is unaffordable. The act of branding pensions as unaffordable now, suggests that they once were affordable. The issue of affordability, however has consistently been used to argue the case against universal pensions, and was also used 1940s - it is, therefore, an argument that refuses to go away, regardless of how affordable pensions actually are. The agitation over the affordability of pensions, appears therefore, to be connected to political will, rather than strict economic logic - both now, and historically. Indeed, the arguments against pension provision based on affordability both now and in the 1940s are so similar it is difficult not to see systematic political social and economical forces at work.

This leaves us at a potential crossroad is pension provision; the current UK social security system is a testament to the mistakes that were made in the 1940s, and have been made since. The Turner report does not offer forward radical enough recommendations, but it is at least a start. The hope now is that Brown will eventually implement the proposals put forward in the Turner report. To cherry-pick from a document already lacking in progressive proposals would be a disaster for the future of pension provision, and only make, at best, minor alterations to the current pension system.

The situation for those without a secure pension, or without the means to invest in one is only set to worsen. Personal debt in Britain is higher than ever previously recorded and new forms of debt, such as student debt is also on the increase, resulting in young people entering the labour market already with a lifetime of debt. It is also highly likely that there will be an insufficient amount of jobs for university graduates (Brown \& Hesketh 2004). This will potentially lead to people with already large amounts of debt working in jobs that pay low wages.

It is for this reason that any changes to pension provision in the UK needs to address these future concerns, rather than allowing another forty years to pass, before stumbling into another crisis. Proposals for change need to address the potential problems of the future, and also help pensioners that are suffering now - not be based on false hegemonic discourses. 


\section{References}

Age Concern (1987) Women and Pensions, London: Age Concern.

Baldwin, S., \& Falkingham, J., [eds.] (1994.), Social security and social change, Hemel Hempstead: Harvester Wheatsheaf

Beveridge, W., (1942) Social Insurance and Allied Services, cmd 6404, London, HMSO

Blackburn, R., (2002) Banking on Death or, Investing in Life: the history and future of pensions. London: Verso.

Blackburn, R., (2004) 'How to Rescue a Failing Pension Regime: The British Case', New Political Economy 9: 4

Brittan, S, (2004) 'There is no such thing as the state', Financial Times, 17 December.

Brown, P., \& Hesketh, A., The Mismanagement of Talent, Oxford: Oxford University Press, 2004.

Churchill, N., \& Mitchell, M., (2005) Labour's Pension Challenge: Building a Progressive Settlement London: Catalyst Pamphlet

Census (2001) London: HMSO

Davies, B., (2003) Better Pensions: The states responsibility London: Catalyst Pamphlet

Fairclough, N., (2000) New Labour, New Language?, London: Routledge

Fairclough, N., (2003) Analysing Discourse: textual analysis for social research, London:

Routledge

Fleetwood, S., (2005) 'Ontology in Organization and Management Studies: A Critical Realist

Perspective', Organization 12

Hill, J., (2006) From Beveridge to Turner: Demography, Distribution and the Future of

Pensions in the UK, London School of Economics CASE publications, Paper No

CASE/110.

Joseph, J., \& Roberts, J., [eds.] (2004) Realism, Discourse and Deconstruction, London: Routledge

Keay, R., (1987) The Sunday Times ('Woman's Own' supplement) 31 October

Labour Research Department (2007) Personal Account Pensions are Unveiled, January

Mullan, P., (2000) The Imaginary Time Bomb: why an ageing population is not a social problem. London: I.B Tauris

Myles, J., (1984) Old Age in the Welfare State: The Political Economy of Public Pensions. London: Scott Forseman \& Company

Pierson, P., (1994) Dismantling the Welfare State: Regan, Thatcher and the Politics of Retrenchment. Cambridge: Cambridge University Press

Thane, P., (2002) Old Age in English History: past experiences, present issues. London: Oxford University Press 
Thane, P., (2006a) 'The 'Scandal' of Women's Pensions in Britain: how did it come about?' History and Policy

Thane, P., (2006b) Comment: Blair must not repeat Attlee's pension mistake Financial Times May 24

Turner, J. A., (2005) The Pension Commission: Challenges and Choices, London, HMSO

Turner, J. A., (2006) The Pension Commission: A New Pensions Settlement for the TwentyFirst Century, London, HMSO

\section{Notes}

${ }^{1}$ NA, Cabinet, CAB 67/4/5, 1940, Jan 11, Memorandum by the Chancellor of the Exchequer, p. 4.

${ }^{2}$ NA, CAB 67/4/5, 1940, Jan 11, Memorandum by the Chancellor of the Exchequer, p. 6.

${ }^{3}$ Beveridge proposed that the full plan should be introduced over 20 years. This was not followed, and has been suggested as the reason why there is now problem with pension provision.

${ }^{4}$ NA, T161/1448, Treasury Notes, Memorandum, Minutes on Beveridge Report, International Labour Office, Social Security through Social Insurance, 1942, p. 5.

${ }^{5}$ NA, T161/1448, Treasury Notes, Memorandum, Minutes on Beveridge Report, International Labour Office, Social Security through Social Insurance, 1942, p. 6.

${ }^{6}$ NA, T161/1448, Beveridge Report: Sir W. Eady, 17/11/1942

${ }^{7}$ Want, disease, ignorance, squalor, and idleness 